\title{
SOSIALISASI ZAKAT/ SUMBANGAN WAJIB KEAGAMAAN SEBAGAI PENGURANG PENGHASILAN KENA PAJAK
}

\author{
Ledy Famulia*1, Diasti Rastosari ${ }^{2}$, Rendi Renaldi ${ }^{3}$, Abel Ivani Fitri Salsabila ${ }^{4}$ \\ 1,2,3,4 Universitas Sang Bumi Ruwa Jurai \\ e-mail: *11 ledysaburai25@gmail.com, ${ }^{2}$ rastosari.diasti@gmail.com, ${ }^{3}$ rendi.fh.saburai@gmail.com
}

\begin{abstract}
Abstrak
Pajak dan zakat merupakan kewajiban material dari seorang warga negara pada negaranya dan merupakan sumber pendapatan negara yang dipergunakan untuk membiayai pengeluaran serta kebutuhan negara. kedudukan zakat tidak dapat digantikan oleh pajak namun tujuan zakat dapat dikatakan tidak jauh berbeda dari tujuan perpajakan. Perpajakan dan zakat memiliki perbedaan pada sumber yuridiksi, pondasi hipotesis, tujuan, tarif, dan alokasi peruntukan. permasalahan di Indonesia yang mayoritas masyarakatnya adalah muslim, selain sebagai wajib zakat mereka juga dibebani dengan berbagai macam pajak oleh karena itu, Peningkatan pemahaman masyarakat akan pentingnya pembayaran zakat/iuran wajib keagamaan dan pajak yang merupakan suatu kewajiban penting untuk dilakukan, terutama bagi mereka yang tinggal di Desa Sidomulyo, Kecamatan Negeri Katon, Kabupaten Pesawaran. Metode yang digunakan dalam menyelesaikan permasalahan adalah dengan melaksanakan sosialisasi atau penyuluhan hukum terkait zakat atau sumbangan wajib keagamaan sebagai pengurang penghasilan kena pajak. Hasil dari kegiatan ini adalah Kegiatan pengabdian kepada masyarakat berupa sosialisasi/ penyuluhan hukum telah dilaksanakan dengan lancar pada tanggal 30 Desember 2020 tepatnya di Kantor Desa Sidomulyo, Kecamatan Negeri Katon, Kabupaten Pesawaran dengan diikuti oleh 38 peserta dengan persentase keberhasilan $90 \%$.
\end{abstract}

Kata kunci : Pajak, Penghasilan, Sumbangan Wajib Keagamaan, Zakat

\section{Abstract}

Taxes and zakat are material obligations of a citizen in his country and are a source of state income used to finance state expenditures and needs. The position of zakat cannot be replaced by taxes, but the purpose of zakat can be said to be not much different from the purpose of taxation. Taxation and zakat have differences in jurisdictional sources, hypothetical foundations, objectives, rates, and allocations. problems in Indonesia, where the majority of the people are Muslims, apart from being obligatory for zakat, they are also burdened with various kinds of taxes. Therefore, increasing public understanding of the importance of paying zakat/religious contributions and taxes which are an important obligation to do, especially for those who live in Sidomulyo Village, Negeri Katon District, Pesawaran Regency. The method used in solving the problem is to carry out socialization or legal counseling related to zakat or religious compulsory donations as a deduction from taxable income. The result of this activity is that community service activities in the form of socialization / legal counseling have been carried out smoothly on December 30, 2020, precisely at the Sidomulyo Village Office, Katon Negeri District, Pesawaran Regency, followed by 38 participants with a success percentage of $90 \%$.

Keywords : Taxes, Income, Donations of Religious Obligations, Zakat

\section{PENDAHULUAN}

Desa Sidomulyo merupakan salah satu desa yang berada di Kecamatan Negeri Katon,
Kabupaten Pesawaran, Provinsi Lampung. Desa Sidomulyo merupakan Dataran rata, sehingga sebagian besar merupakan areal peladangan, persawahan dan perkebunan. Luas wilayah desa 
Sidomulyo tersebut kurang lebih 1.182 Hektar atau seluas $11,82 \mathrm{~km}^{2}$.

Jumlah penduduk di Desa Sidomulyo berjumlah 4.692 Jiwa, dengan jumlah jiwa lakilaki sebanyak 2.368 orang dan jumlah jiwa perempuan sebanyak 2.241 orang. Sedangkan jumlah Kepala Keluarga adalah sebanyak 1.384 KK yang tersebar di 9 dusun. Mata pencaharian penduduk Sidomulyo mayoritas adalah petani, sebagian yang lain sebagai karyawan/ PNS, dan yang lainnya berwiraswasta.

Desa Sidomulyo sebagai salah satu desa yang memiliki potensi dalam kaitannya dengan kewajiban zakat dan pajak penghasilan tentunya merupakan salah satu wilayah yang wajib disentuh melalui kegiatan sosialisasi guna meningkatkan kesadaran masyarakat untuk membayar zakat dan pajak dalam kaitannya dengan penghasilan, serta memahami bahwa mereka tidak dikenakan beban ganda atas kedua kewajiban tersebut.

Dalam kaitannya dengan penghasilan, seorang penduduk apapun pekerjaannya pasti memiliki penghasilan bulanan baik itu penghasilan tetap maupun tidak tetap [1], baik yang jumlahnya pasti maupun yang tidak pasti. Tiap daerah berhak membebankan pungutan biaya kepada masyarakat yang berupa pajak [2] atas penghasilan yang didapatkan seorang sebagai warga negara yang jumlahnya disesuaikan dengan jumlah penghasilan yang didapatkan. Untuk penduduk yang berprofesi sebagai karyawan atau PNS, semua alur pemotongan pajak tersebut sudah dipotong sebelumnya ketika ASN [3] atau karyawan menerima gaji secara berkala. Namun, bagi petani maupun wiraswasta butuh kesadaran untuk dapat membayarkan pajak atas penghasilan mereka.

Selain pajak, kewajiban yang dibebankan kepada seorang yang beragama adalah zakat yaitu kewajiban mutlak bagi seorang muslim [4] atau sumbangan wajib keagamaan bagi nonmuslim. Berbagai jenis zakat yang berpotensi untuk dikumpulkan [5], salah satunya adalah zakat atas penghasilan. Sepintas, kedua kewajiban ini nampak seperti beban ganda. Untuk menyiasati hal tersebut, pemerintah membuat kebijakan yakni zakat atau sumbangan wajib keagamaan dapat menjadi pengurang penghasilan kena pajak. Hal ini diakomodir dalam UU Pajak Penghasilan dan UU Zakat.

Dalam kaitannya dengan kebijakan tersebut, banyak warga masyarakat yang belum mengetahuinya, termasuk warga Desa Sidomulyo, Kecamatan Negeri Katon, Kabupaten Pesawaran. Apabila masyarakat memahami kebijakan ini, pemerintah akan lebih dapat memaksimalkan pengumpulan zakat dan pajak di Indonesia karena masyarakat memahami bahwa keduanya merupakan kewajiban dan mereka tidak dikenakan beban ganda atas satu objek yang sama tersebut.

Demikian penting kesadaran penduduk setempat maka akan membawa pengaruh besar stabilisasi ekonomi pemerintah yang juga demi 
menciptakan kesejahteraan masyarakat setempat. Hal ini didasarkan pada peruntukan zakat yang mencangkup 8 asnaf (fakir, miskin, riqab atau budak, qharimin atau orang yang berhutang, sabilillah orang yang berjuang di jalan Allah, ibnusabil atau orang yang berpergian jauh, muallaf, amilin atau orang yang bertugas mengumpulkan zakat)[6]. Kedelapan asnaf tersebut biasanya dikemas sedemikian rupa dengan berbagai program yang dilakukan oleh amil resmi yang ditunjuk oleh pemerintah, baik Lembaga Amil Zakat (LAZ) maupun Badan Amil Zakat (BAZ)[7] dalam proses distribusinya, sehingga hal ini tentu sangat bermanfaat dan pasti akan kembali kepada masyarakat setempat terutama bagi mereka yang berhak dan membutuhkan. Sedangkan pajak juga akan dikelola sedemikian rupa baik oleh pemerintah pusat maupun pemerintah daerah sehingga juga memberikan kemanfaatan bagi masyarakat setempat.

\section{METODE}

\subsection{Metode yang Digunakan}

Metode yang digunakan dalam menyelesaikan permasalahan adalah dengan melaksanakan sosialisasi atau penyuluhan hukum terkait zakat atau sumbangan wajib keagamaan sebagai pengurang penghasilan kena pajak dengan tahapan-tahapan sebagai berikut:

1. Tahap persiapan dengan cara menyusun materi dalam kaitannya dengan zakat atau sumbangan wajib keagamaan sebagai pengurang penghasilan kena pajak.

2. Persiapan lokasi sosialisasi dengan menambahkan beberapa peralatan guna menerapkan protokol kesehatan, yakni tempat mencuci tangan dan face shield karena kegiatan ini dilakukan di masa pandemi covid-19.

3. Melaksanakan sosialisasi atau penyuluhan hukum kepada warga yang berdomisili di Desa Sidomulyo, Kecamatan Negeri Katon, Kabupaten Pesawaran, terkait dengan kebijakan zakat sebagai pengurang penghasilan kena pajak.

4. Bentuk kegiatan berupa sosialisasi kebijakan pemerintah terkait zakat sebagai pengurang penghasilan kena pajak ini dilakukan secara langsung yakni dengan tatap muka dan berdialog dengan masyarakat dengan dihadiri oleh camat, lurah, serta ketua RT dan petugas kebersihan daerah setempat.

\subsection{Jadwal Kegiatan}

Jadwal kegiatan sosialisasi zakat atau sumbangan wajib keagamaan sebagai pengurang penghasilan kena pajak adalah sebagai berikut: 
Tabel 1. Jadwal Kegiatan

\begin{tabular}{|c|c|c|}
\hline No. & Nama Kegiatan & Waktu \\
\hline 1. & $\begin{array}{l}\text { Persiapan dan Registrasi } \\
\text { Peserta }\end{array}$ & $08.00-08.30 \mathrm{WIB}$ \\
\hline 2. & Pembukaan & $08.30-09.00 \mathrm{WIB}$ \\
\hline \multirow[t]{5}{*}{3.} & Sambutan - sambutan: & \\
\hline & $\begin{array}{ll}\text { a. } & \text { Kepala Desa } \\
& \text { Sidomulyo }\end{array}$ & $09.00-09.30 \mathrm{WIB}$ \\
\hline & b. Ketua LPM & \\
\hline & Universitas Sang & $09.30-10.00 \mathrm{WIB}$ \\
\hline & Bumi Ruwa Jurai & \\
\hline \multirow[t]{5}{*}{4.} & Pelaksanaan Kegiatan: & \\
\hline & a. Sosialisasi "Zakat & \\
\hline & $\begin{array}{l}\text { sebagai pengurang } \\
\text { Penghasilan Kena }\end{array}$ & $10.00-11.30 \mathrm{WIB}$ \\
\hline & Pajak" & \\
\hline & b. Tanya Jawan & $11.30-12.00 \mathrm{WIB}$ \\
\hline 5. & Penutup & $12.00 \mathrm{WIB}$ \\
\hline
\end{tabular}

\section{HASIL DAN PEMBAHASAN}

\subsection{Laporan Kegiatan}

Kegiatan pengabdian kepada masyarakat berupa sosialisasi/ penyuluhan hukum dengan tema "Zakat Atau Sumbangan Wajib Keagamaan Sebagai Pengurang Penghasilan Kena Pajak" telah dilaksanakan dengan lancar. Kegiatan tersebut dilaksanakan pada tanggal 30 Desember 2020 tepatnya di Kantor Desa Sidomulyo, Kecamatan Negeri Katon, Kabupaten Pesawaran dengan diikuti oleh 38 peserta yang merupakan warga Desa Sidomulyo.

Kegiatan sosialisasi dimulai pada pukul 08.00 WIB - 12.00 WIB. Dalam pelaksanaannya, masyarakat terlihat cukup antusias, hal ini dibuktikan dengan banyaknya pertanyaan yang diajukan berkaitan dengan tema yang dibahas seperti bagaimana jika zakat dibayarkan pada amil perorangan, bukan pada lembaga berbadan hukum seperti Badan Amil Zakat atau Lembaga Amil Zakat, selain itu juga mereka menanyakan bagaimana cara menghitung harta yang sudah mencapai nisab sehingga wajib dizakati, padahal penghasilan mereka tidak pasti karena mayoritas adalah petani, dan lain sebagainya. Presentase keberhasilan sosialisasi ini mencapai 90\%, hal ini didukung dengan turut hadirnya beberapa perangkat desa seperti ketua RT, RW, lurah, dan camat desa setempat yg tentu dapat membantu tercapainya pehaman masyarakat setempat.

\subsection{Evaluasi Kegiatan}

Meskipun kegiatan ini telah dilaksanakan dengan lancar, namun terdapat beberapa hal yang harus dievalusasi, diantaranya:

1. Kegiatan tidak dapat dilaksanakan dengan tepat waktu, banyak masyarakat yang datang terlambat sehingga tidak dapat mendengarkan materi secara utuh.

2. Kegiatan dilaksanakan pada hari kerja, sehingga masyarakat yang bekerja sebagai PNS maupun sebagai karyawan tidak banyak yang dapat hadir pada kegiatan sosialisasi ini.

3. LCD dan proyektor milik desa setempat sedang dalam perbaikan, sehingga materi presentasi yang telah disiapkan tidak dapat ditampilkan. 
Padahal terdapat beberapa contoh penghitungan zakat atau iuran wajib keagamaan sebagai pengurang penghasilan kena pajak.

\section{SIMPULAN}

Kegiatan pengabdian kepada masyarakat dilaksanakan dalam rangka melaksanakan tridharma perguruan tinggi yang tentu wajib untuk dilaksanakan. Dalam kesempatan ini, pengabdian kepada masyarakat dilaksanakan dengan melakukan kegiatan sosialisasi / penyuluhan hukum dengan tema "Zakat Atau Sumbangan Wajib Keagamaan Sebagai Pengurang Penghasilan Kena Pajak”.

Dengan adanya kebijakan ini, maka tidak ada lagi beban ganda terhadap satu objek yang sama yakni pembayaran zakat dan pajak atas satu penghasilan. Pemerintah memilih kebijakan dengan mengurangkan penghasilan yang dikenakan pajak apabila telah membayar zakat atau sumbangan wajib keagamaan dengan syaratsyarat tertentu. Sosialisasi terkait aturan tersebut telah dilaksanakan dengan lancar dengan diikuti oleh 38 peserta. Dengan adanya kebijakan ini, diharapkan potensi zakat dan pajak terutama yang terdapat dalam Desa Sidomulyo dapat terealisasi secara maksimal, sehingga nantinya dapat menjadi salah satu cara untuk memperkuat perekonomian desa setempat.

Terdapat kekurangan pada kegiatan ini, antara lain :
1. Kegiatan tidak dapat dilaksanakan dengan tepat waktu, banyak masyarakat yang datang terlambat sehingga tidak dapat mendengarkan materi secara utuh.

2. Kegiatan dilaksanakan pada hari kerja, sehingga masyarakat yang bekerja sebagai PNS maupun sebagai karyawan tidak banyak yang dapat hadir pada kegiatan sosialisasi ini.

3. LCD dan proyektor milik desa setempat sedang dalam perbaikan, sehingga materi presentasi yang telah disiapkan tidak dapat ditampilkan. Padahal terdapat beberapa contoh penghitungan zakat atau iuran wajib keagamaan sebagai pengurang penghasilan kena pajak.

\section{SARAN}

Kegiatan sosialisasi dengan tema "Zakat Atau Sumbangan Wajib Keagamaan Sebagai Pengurang Penghasilan Kena Pajak" dilaksanakan dengan lancar. Namun meski demikian, terdapat beberapa kekurangan dalam kegiatan sehingga terdapat beberapa saran yang perlu disampaikan sebagai berikut:

1. Kegiatan sosialisasi / penyuluhan hukum hendaknya dilakukan pada hari libur, agar masyarakat terutama yang bekerja sebagai karyawan maupun PNS dapat mengikuti, 
terutama terkait tema-tema yang diperuntukkan bagi mereka juga.

2. Bagi masyarakat hendaknya perlu ditingkatkan kedisiplinan terutama dalam kaitannya dengan waktu.

3. Bagi perangkat desa, hendaknya dilakukan perawatan sebaik-baiknya terhadap peralatan yang ada sehingga seluruh rangkaian kegiatan sosialisasi dapat dilaksanakan secara maksimal.

\section{UCAPAN TERIMA KASIH}

Penulis mengucapkan terima kasih kepada Dekan Fakultas Hukum, Ibu Dr. Lina Maulidiana, S.H.,M.H. yang telah memberi dukungan sehingga kegiatan pengabdian masyarakat ini berjalan dengan lancar. Penulis juga mengucapkan terimakasih kepada LPPM Universitas Sang Bumi Ruwa Jurai yang telah memfasilitasi kegiatan ini baik secara moral maupun finansial sehingga penulis dapat mengikuti program pengabdian masyarakat ini.

\section{DAFTAR PUSTAKA}

[1] P. Umami, L. A. Abdillah, and I. Z. Yadi, "Sistem pendukung keputusan pemberian beasiswa bidik misi," arXiv Prepr.

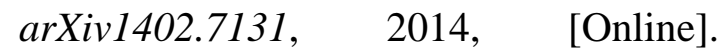
Available: http://arxiv.org/abs/1402.7131.

[2] F. D. Siregar, "Analisis Hukum
Kebijakan Sanksi Pidana Terhadap Penunggak Pajak Kendaraan Bermotor (Studi Penelitian Pada Samsat Medan Utara)," J. Huk. dan Kemasyarakatan AlHikmah, vol. 1, no. 1, pp. 32-48, 2020.

[3] M. T. Rahman, M. Hidayat, and A. Djalante, "Analisis Perbedaan Pengelolaan Pemungutan $\mathrm{PPh} 21$ Aparatur Sipil Negara (ASN) Sebelum dan Sesudah Implementasi Peraturan Direktorat Jenderal Pajak No. 32/PJ/2017 (Studi Kasus di Kantor Pemerintah Daerah Kabupaten Bulukumba)," AkMen J. Ilm., vol. 17, no. 4, pp. 583-589, 2020.

[4] S. Nurhasanah and Suryani, "Maksimalisasi Potensi Zakat Melalui Peningkatan Kesadaran Masyarakat," JEBI (Jurnal Ekon. dan Bisnis Islam., vol. 3, no. 2, pp. 185-194, 2018, doi: 10.15548/jebi.v3i2.177.

[5] I. Idris and T. Yahya, "Peranan Lembaga Zakat Dalam Pungutan Harta Zakat di Badan Amil Zakat Daerah Kabupaten Muaro Jambi," J. Selat, vol. 6, no. 1, pp. 115-124, 2018, doi: 10.31629/selat.v6i1.646.

[6] L. S. Pratama, "Analisis Kinerja Lembaga Zakat Infaq dan Shodaqoh Dengan Metode Balanced Scorecard (Studi Kasus pada Lazis Al-Ihsan Jawa Tengah Cabang Solo Raya)," Acad. J. Multidiscip. Stud., vol. 2, no. 2, pp. 233246, 2018. 
[7] E. Hartatik, "Analisis Praktik

Pendistribusian Zakat Produktif Pada

Badan Amil Zakat Daerah (BAZDA)

Kabupaten Magelang," Az Zarqa', vol. 7, no. 1 , pp. $30-47,2015$. 